\title{
The Opitz syndrome gene product MID1 assembles a microtubule-associated ribonucleoprotein complex
}

\author{
Beatriz Aranda-Orgillés · Alexander Trockenbacher · Jennifer Winter · Johanna Aigner • \\ Andrea Köhler $\cdot$ Ewa Jastrzebska $\cdot$ Joachim Stahl $\cdot$ Eva-Christina Müller • \\ Albrecht Otto $\cdot$ Erich E. Wanker $\cdot$ Rainer Schneider $\cdot$ Susann Schweiger
}

Received: 24 October 2007 / Accepted: 15 December 2007 / Published online: 3 January 2008

(C) Springer-Verlag 2007

\begin{abstract}
Opitz BBB/G syndrome (OS) is a heterogenous malformation syndrome mainly characterised by hypertelorism and hypospadias. In addition, patients may present with several other defects of the ventral midline such as cleft lip and palate and congenital heart defects. The syndrome-causing gene encodes the X-linked E3 ubiquitin ligase MID1 that mediates ubiquitin-specific modification and degradation of the catalytic subunit of the translation regulator protein phosphatase 2A (PP2A). Here, we show that the MID1 protein also associates with elongation factor $1 \alpha(\mathrm{EF}-1 \alpha)$ and several other proteins involved in mRNA transport and translation, including RACK1, Annexin A2, Nucleophosmin and proteins of the small ribosomal subunits. Mutant MID1 proteins as found in OS patients lose the ability to interact with EF-1 $\alpha$. The composition of the MID1 protein complex was determined by several independent methods: (1) yeast two-hybrid screening and (2) immunofluorescence, (3) a biochemical approach involving affinity purification of
\end{abstract}

Electronic supplementary material The online version of this article (doi:10.1007/s00439-007-0456-6) contains supplementary material, which is available to authorized users.

B. Aranda-Orgillés · A. Trockenbacher · J. Winter ·

J. Aigner $\cdot$ R. Schneider $\cdot$ S. Schweiger

Max-Planck Institute for Molecular Genetics,

Ihnestr. 73, 14195 Berlin, Germany

e-mail: aranda@molgen.mpg.de

B. Aranda-Orgillés

Department of Biology, Chemistry and Pharmacy,

Free University Berlin, Thielallee 63, 14195 Berlin, Germany

A. Trockenbacher · A. Köhler · R. Schneider $(\varangle)$ Institute of Biochemistry, Center for Molecular Biosciences Innsbruck (CMBI), University Innsbruck,

Peter-Mayr-Str. 1a, 6020 Innsbruck, Austria

e-mail: rainer.schneider@uibk.ac.at the complex, (4) co-fractionation in a microtubule assembly assay and (5) immunoprecipitation. Moreover, we show that the cytoskeleton-bound MID1/translation factor complex specifically associates with G- and U-rich RNAs and incorporates MID1 mRNA, thus forming a microtubule-associated ribonucleoprotein (RNP) complex. Our data suggest a novel function of the OS gene product in directing translational control to the cytoskeleton. The dysfunction of this mechanism would lead to malfunction of microtubule-associated protein translation and to the development of OS.

\section{Introduction}

Opitz BBB/G syndrome (OS) is a heterogeneous malformation syndrome resulting from defective development of the ventral midline and is characterised by hypertelorism, hypospadias, cleft lip and palate, tracheo-esophageal malformations and congenital heart defects (Opitz et al. 1969a, b). Mutations in the RING finger protein MID1 cause the X-linked form of the syndrome (Quaderi et al. 1997). MID1 associates with microtubules and its ubiquitin ligase activity

\section{E. Jastrzebska}

Max-Planck Institute for Molecular Genetics,

Ihnestr. 73, 14195 Berlin, Germany

\section{E. Jastrzebska}

Department of Dermatology, Charité,

Schumannstr. 21-22, 10117 Berlin, Germany

J. Stahl · E.-C. Müller · A. Otto · E. E. Wanker

Max-Delbrueck Center of Molecular Medicine,

Robert-Roessle-Str. 10, 13125 Berlin, Germany

S. Schweiger

Medical School, Division of Pathology and Neuroscience,

University of Dundee, DD1 9SY Dundee, UK 
regulates the ubiquitin-specific modification and degradation of the microtubule-associated catalytic subunit of protein phosphatase 2Ac (PP2Ac; Trockenbacher et al. 2001). PP2A is an important player in the mTOR pathway: opposing mTOR kinase, PP2A dephosphorylates 4E-BP1 and S6K1, and thereby down-regulates translation of mRNAs containing oligopyrimidine tracts at their $5^{\prime}$ transcription start site, so-called 5'TOP sequences (reviewed in Jacinto and Hall 2003). In OS patients, MID1-mediated regulation of PP2Ac turnover is disrupted, which leads to hypophosphorylation of PP2A targets (Short et al. 2002; Trockenbacher et al. 2001).

Proper ventral midline development requires the establishment of cellular asymmetry and cell polarity, which, in turn, requires the targeting of mRNAs to specific cellular regions (Bashirullah et al. 1998; Dreyfuss et al. 2002; Lasko 1999; Mohr and Richter 2001). While several mechanisms have been proposed for the achievement of regionspecific clustering of proteins, both the active transport of mRNAs along the cytoskeleton and compartmentalised protein translation in mRNA-containing protein complexes (mRNP complexes) appear to be essential (reviewed in Bassell and Singer 2001; Condeelis and Singer 2005; Pokrywka and Stephenson 1995). In addition, mRNPs are involved in suppressing premature translation of localised mRNAs, and only when the transcripts have reached their proper destinations, a switch takes place and the mRNPs induce translation of their mRNA cargoes (Nakamura et al. 2004; Webster et al. 1997; Zalfa and Bagni 2005). In this way, mRNPs help to keep separate the processes of mRNA transport and translation.

Here, we demonstrate that the PP2Ac regulator MID1 interacts with elongation factor $1 \alpha(\mathrm{EF}-1 \alpha)$, another important regulatory factor of protein translation. Mutant MID1 proteins as found in OS patients cannot bind EF- $1 \alpha$, suggesting an important role of this interaction in the development of the ventral midline. Furthermore, MID1, the regulatory PP2A subunit $\alpha 4$ and EF- $1 \alpha$ seem to be at the core of a large microtubule-bound multiprotein complex that associates with RNA and with several other factors involved in mRNA transport and translational control, thus forming a ribonucleoprotein (RNP) complex. Our data supports a novel function of MID1 in directing mRNP complex-associated protein translation regulation to the cytoskeleton, malfunction of which would explain the observed developmental malformations in OS.

\section{Materials and methods}

Antibodies

Anti-MID1 and anti- $\alpha 4$ antibodies have been described previously (Schweiger et al. 1999; Trockenbacher et al. 2001).
Antibodies against ribosomal proteins were prepared as described (Lutsch et al. 1990). Commercially available antibodies were used for the detection of Hsc70 and Hsp90 (both from Stressgene), EF-1 $\alpha$ (Upstate), NPM (Zymed), RACK1, ANXA2 (both from BD Biosciences), Tubulin $\alpha / \beta$ (Serotec), anti-HuR (Santa Cruz Biotechnologies), monoclonal anti-FLAG (Stratagene) and anti-hnRNPA1 (Sigma).

\section{Constructs}

The sequence encoding a 44 amino acid peptide (aa236aa280) of the $\alpha 4$ protein was cloned between the $B g I I I$ and BamHI sites of the PinPoint ${ }^{\mathrm{TM}} \mathrm{Xa}$ vector (Promega). Subsequently, an oligonucleotide coding for a 6x His-RGSTAG was added between the BamHII and HindIII sites. The MID1 open reading frame was cloned between the EcoRI and HindIII sites of the multiple cloning site of the pCMVTag2a-Vector (Stratagene).

Full length MID1 cDNA (NM_000381) was cloned in frame in pECFP-C1 (Clontech) using XhoI-SalI sites translating in an MID1 protein expressed as fusion to the C-terminus of ECFP. Full length EF-1 $\alpha$ (NM_001402) was cloned into pBudCE4.1 (Invitrogen) using SalI-BamHI sites translating in an EF- $1 \alpha$ protein expressed as fusion to the N-terminus of myc-tag.

Yeast two-hybrid analysis

Screening was performed according to the manufacturer's protocol (Stratagene Cytotrap-System). For mapping the protein interaction sites on MID1, we also used the yeast two-hybrid CytoTrap system from Stratagene. Full length and truncated MIDI cDNA were cloned into the pSOS vector and full-length EF- $1 \alpha$ cDNA into the pMYR vector. Both vectors were then co-transfected into the $\operatorname{cdc} 25 \mathrm{H}$ yeast strain and the transformants were plated on synthetic medium lacking leucine and uracil (leu- ura-) containing dextrose and incubated at $24^{\circ} \mathrm{C}$ for $4-5$ days. To test whether the two proteins interact, positive colonies were replica plated on SD (leu- ura-) plates containing dextrose and galactose, respectively, and incubated at $37^{\circ} \mathrm{C}$ for 6-10 days. Growth at $37^{\circ} \mathrm{C}$ on galactose plates indicated protein interaction, while plates containing dextrose served as control for temperature revertants.

Immunofluorescence and image acquisition

COS-7 were transfected with pECFP-MID1 and pBud-EF$1 \alpha$-myc on coverslips. At $24 \mathrm{~h}$ after transfection, the cells were fixed in ice cold methanol $\left(20 \mathrm{~min}\right.$, at $\left.-20^{\circ} \mathrm{C}\right)$, pre-incubated for $30 \mathrm{~min}$ in 5\% normal goat serum (Invitrogen), and incubated overnight with primary rabbit polyclonal to myc-tag antibody (Abcam ab106-100; dilution 
1:400) in PBS containing $0.2 \%$ BSA. The cells were washed five times in the same buffer and incubated for $1 \mathrm{~h}$ with Alexa Fluor 595 goat anti-rabbit (Molecular Probes, 1:4000) as secondary antibody. After washing, the cells were mounted on glass slides with Mowiol and visualised with an Olympus BX50 microscope equipped with filter cubes (Chroma) optimised for ECFP and Alexa Fluor 595. Images were captured in black and white, colourised, and merged to show the relative distribution of both stains.

Tissue culture and immunoprecipitation

HeLa cells were transfected with lipofectamine following the manufacturer's (Invitrogen) protocol. After $48 \mathrm{~h}$, the cells were homogenised by sonication in Hepes-Sucrose buffer (HS, $4 \mathrm{mM}$ Hepes, 0.32 M sucrose), containing $150 \mathrm{mM} \mathrm{NaCl}$ and a cocktail of proteinase inhibitors (complete mini, Roche), and centrifuged for $15 \mathrm{~min}$ at $12,000 \mathrm{~g}$ at $4^{\circ} \mathrm{C}$. Cytosolic extract, $1 \mathrm{mg}$, was immunoprecipitated with $40 \mu \mathrm{l}$ anti-FLAG M2-coated beads (Sigma) in $1 \mathrm{ml} \mathrm{HS}$ buffer overnight. The beads were washed three times for $10 \mathrm{~min}$ at $4^{\circ} \mathrm{C}$ with HS buffer and eluted for $45 \mathrm{~min}$ with $3 \times$ FLAG peptide (Sigma). Co-immunoprecipitated proteins were analysed on $10 \%$ SDS-gels using the corresponding antibodies.

Endogenous immunoprecipitation with cytosolic cell lysates was performed overnight with $5 \mu \mathrm{g}$ of EF- $1 \alpha$ antibody or mouse $\mathrm{IgG}$ and $40 \mu \mathrm{l}$ of protein-G slurry (Roche) in HSMN buffer (HS buffer supplemented with $5 \mathrm{mM}$ $\mathrm{MgCl}_{2}, 100 \mathrm{mM} \mathrm{NaCl}$ ) containing $0.5 \% \mathrm{NP}-40$. After washing three times with HSMN buffer as above, bound proteins were boiled and analysed with the different antibodies on a Western blot.

\section{Affinity chromatography}

Recombinant 44 aa peptide was overexpressed in E.coli in the presence of $2 \mu \mathrm{M}$ biotin, lysed in native conditions lysis buffer $\left(50 \mathrm{mM} \mathrm{NaH} \mathrm{PO}_{4}, 300 \mathrm{mM} \mathrm{NaCl}, 10 \mathrm{mM}\right.$ imidazole, $\mathrm{pH}$ 8.0) with multiple thaw and freeze cycles and purified using Ni-NTA agarose according to the manufacturer's protocol (QiaExpressionist ${ }^{\mathrm{TM}}$, Qiagen). Biotinylated peptide, $50 \mu \mathrm{g}$, in binding buffer was incubated with $250 \mu \mathrm{l}$ of streptavidin-coated agarose slurry (PIERCE, ProFound ${ }^{\mathrm{TM}}$ Pull-Down kit) for $1 \mathrm{~h}$ at $4^{\circ} \mathrm{C}$ rotating in a $500 \mu \mathrm{l}$ reaction, blocked with free biotin for $5 \mathrm{~min}$, washed with HS buffer and blocked with $1 \mathrm{mg} / \mathrm{ml}$ BSA overnight at $4{ }^{\circ} \mathrm{C}$. After washing with 100 volumes of $\mathrm{HS}$ and 2 volumes of washing buffer (250 mM NaCl, $0.05 \%$ Tween), the column was incubated with cytoplasmic HeLa extract from $3 \times 10^{7}$ cells, previously subjected to $\alpha 4$ knockdown, at $4^{\circ} \mathrm{C}$ overnight, again washed with 100 volumes of HS and 2 volumes of washing buffer and eluted $3 \times 15 \mathrm{~min}$ with excess of free, thrombin-digested 44 aa peptide produced with a pET32a system (Novagen). Elution fractions were dialysed against $20 \mathrm{mM}$ Tris- $\mathrm{HCl}, \mathrm{pH} 8.0$, run on a $10 \%$ SDS gel and stained with colloidal Coomassie as previously described (Neuhoff et al. 1988). Specific bands were excised, trypsinised and analysed with mass spectrometry.

Mass spectrometry

The peptide mixture was identified by chromatographic separation on an LC Packings $75 \mu \mathrm{m}$ PepMap C18 column (Dionex, Idstein, Germany) using a capillary liquid chromatography (CapLC) system delivering a gradient to formic acid $(0.1 \%)$ and acetonitrile $(80 \%)$. Eluted peptides were ionised by electrospray ionisation on a Q-TOF hybrid mass spectrometer (Micromass, Manchester, UK). The mass spectral data were processed into peak lists containing the $m / z$ value, charge state of the parent ion, fragment ion masses and intensities, and correlated with the SwissProt database using Mascot software (Perkins et al. 1999).

In vitro assembly of microtubules

Microtubules were polymerised in vitro from $3 \times 10^{7} \mathrm{HeLa}$ cells according to previously reported protocols (Kimble et al. 1992; Vallee 1982) at $37^{\circ} \mathrm{C}$. As control, a sample was continuously maintained under cold-shock conditions. After purification, microtubule-associated proteins were analysed by Western blot with the corresponding panel of antibodies.

siRNA transfection

According to Invitrogen's protocol, $4 \times 10^{5} \mathrm{HeLa}$ cells/ $75 \mathrm{~cm}^{2}$ tissue culture were grown in DMEM medium with $10 \%$ foetal bovine serum and transfected with $40 \mu \mathrm{l}$ of $20 \mu \mathrm{M} \alpha 4$ siRNA (sense: GUACCUUUUGGUGCCA GCG) or non-silencing oligonucleotides and $40 \mu \mathrm{l}$ of Oligofectamine $^{\mathrm{TM}}$ (Invitrogen) in OptiMEM. After $48 \mathrm{~h}$, the cells were harvested and the efficiency of the knockdown was tested by Western blotting with a specific antibody against $\alpha 4$.

RNA-protein binding assays

HeLa cells were homogenised in HSMN buffer with proteinase inhibitors (Roche) and Prime RNase inhibitor (Eppendorf) in a Potter-Elvehjem. Cytosolic fractions were cleared by centrifugation for $15 \mathrm{~min}$ at $12,000 \mathrm{~g}$. Protein binding assay with homoribopolymers was performed as described previously (Kiledjian and Dreyfuss 1992; Siomi et al. 1993). 
MID1 complex immunoprecipitation, RNA extraction and RNA labeling

Cytosolic extracts, $4 \mathrm{mg}$, from HeLa cells overexpressing MID1-FLAG homogenised in TKM buffer $(20 \mathrm{mM}$ Tris, $150 \mathrm{mM} \mathrm{KCl}, 5 \mathrm{mM} \mathrm{MgCl}$ ) supplemented with proteinase inhibitors and $0.1 \%$ NP40 were precleared with $25 \mu \mathrm{l}$ of protein-A/G agarose (Roche) and $10 \mu \mathrm{g}$ of mouse IgG for $1.5 \mathrm{~h}$ at $4^{\circ} \mathrm{C}$ on a rocking platform. The beads were pelleted by centrifugation for $1 \mathrm{~min}$ at 3,000 rpm at $4^{\circ} \mathrm{C}$ and discarded. The supernatant was immunoprecipitated with $75 \mu \mathrm{l}$ of antiFLAG $^{\circledR}$ M2 affinity gel (Sigma-Aldrich) overnight. AntiFLAG $^{\circledR} \mathrm{M} 2$ agarose matrix had been previously equilibrated in TKM buffer, blocked with $1 \mathrm{mg} / \mathrm{ml}$ BSA for $30 \mathrm{~min}$ and washed again with TKM buffer. Immunoprecipitated complexes were washed three times with $500 \mu \mathrm{T}$ TKM buffer supplemented with $0.2 \% \mathrm{NP} 40$ for $10 \mathrm{~min}$ at $4{ }^{\circ} \mathrm{C}$. Bound proteins were eluted for $45 \mathrm{~min}$ with $200 \mu \mathrm{l}$ of $3 \times$ FLAG peptide and, after keeping an aliquot for Western blot, treated with 10 units of DNase I for $30 \mathrm{~min}$ at $37^{\circ} \mathrm{C}$ and subsequently, with $100 \mu \mathrm{g}$ proteinase $\mathrm{K}$ for $20 \mathrm{~min}$ at $37^{\circ} \mathrm{C}$. Bound RNA was isolated by phenol/chloroform extraction, followed by ethanol precipitation. For RNA-labeling, $8 \mu \mathrm{l}$ of the extracted RNA were labelled using $2 \mu \mathrm{l}$ of RNA ligase and $30 \mu \mathrm{Ci}$ of cytidine $3^{\prime}, 5^{\prime}$-bis(phosphate) (pCp; $5^{\prime}{ }^{32} \mathrm{P}-$ labelled; PerkinElmer Life Sciences) in a final volume of $20 \mu \mathrm{l}$ and incubated for $2 \mathrm{~h}$ at $37^{\circ} \mathrm{C}$, as previously described (Filipenko et al. 2004). Labeled RNA was purified through a NucAway ${ }^{\mathrm{TM}}$ spin column (Ambion) and $2 \mu \mathrm{l}$ was loaded on an $1 \%$ agarose gel for qualitative analysis. The gel was dried under vacuum, and the labelled RNA was visualised by autoradiography. In addition, incorporation of the pCp label was assessed quantitatively by scintillation counting. As control, the same procedure was performed with cell lysates overexpressing the empty FLAG vector. In addition to the labeling, cDNA was synthesised using random primers and this was subsequently used for RT-PCR with primers from the coding region of the MID1 gene (F: 5'-CAT GCG CGT TTC CTA CAG AC-3'; R: 5'-GCC TCT TAA TGT GCA CCA AG-3'; nested: F: 5'-TCG AAA ACT GAA GGT GTC CC-3', R: 5' -TCA CGG CAG CTG CTC TG-3') and as negative control PIP (NM_002652; F: 5'-CTC CTG GTT CTC TGC CTG-3', R: 5'-GAC CAC AGC AGA AAT TCC AG-3'; nested: F: 5'-CAA CAA AGC TCA GGA CAA CAC-3', R: 5'-GAG GAA ATC ACC TGG GTG TG-3'). This time as negative control for the immunoprecipitation, HeLa lysates containing overexpressed FLAG-MID1 were pulled down with mouse IgG.

mRNA in situ hybridisation

U373 cells grown on coverslips were washed with $1.2 \times$ PEM (120 mM Pipes, 6 mM EGTA, $2.4 \mathrm{mM} \mathrm{MgCl}_{2}, \mathrm{pH}$
7.0) under microtubule-preserving conditions, fixed with $4 \%$ paraformaldehyde, washed with PBS and permeabilised in $70 \%$ EtOH overnight. After washing in $2 \times$ SSC, $50 \%$ formamide for $5 \mathrm{~min}$, the coverslips were incubated overnight at $37^{\circ} \mathrm{C}$ with six different $5^{\prime}$-Dig labeled MID1 oligonucleotide probes (37.5 ng each; for sequences see Table S1) or a 5 '-Dig labeled nonsense oligonucleotide (225 ng total) as a negative control in hybridisation buffer $(2 \times \mathrm{SSC}, 50 \%$ formamide, $0.02 \% \mathrm{BSA}, 1 \mu \mathrm{g} / \mu \mathrm{l}$ yeast tRNA, $10 \%$ dextran sulphate). Subsequently, coverslips were washed twice in $2 \times$ SSC with $50 \%$ formamide for $30 \mathrm{~min}$ at $37^{\circ} \mathrm{C}$ and incubated with alkaline phosphatase coupled anti-Dig antibody (Roche) at a concentration of 1:500 overnight at $4^{\circ} \mathrm{C}$. For co-staining of the centrosome, coverslips were incubated with a monoclonal antibody directed against $\gamma$-tubulin (1:1,000; Sigma-Aldrich) for $1 \mathrm{~h}$ at room temperature. On the next day, the coverslips were washed twice with $2 \times$ SSC, $8 \%$ formamide, once with alkaline phosphatase buffer (100 mM Tris pH 9.5, $50 \mathrm{mM} \mathrm{MgCl}_{2}, 100 \mathrm{mM} \mathrm{NaCl}, 0.1 \%$ Tween20) and once with alkaline phosphatase buffer containing levamisole at room temperature. For detection, the coverslips were incubated with NBT/BCIP overnight at $4^{\circ} \mathrm{C}$ and mounted with Vecta-DAPI.

\section{Results}

MID1 directly interacts and colocalises with EF- $1 \alpha$

In order to identify novel protein interaction partners of the MID1 protein, we screened a CytoTrap ${ }^{\circledR}$ XR Human Prostate cDNA Library (MID1 is highly expressed in prostate tissue; http://symatlas.gnf.org/SymAtlas/) with a pSOS+ MID1-Cterm construct using the CytoTrap yeast two-hybrid system. The pSOS+MID1-Cterm construct contained the C-terminus of MID1 from amino acid 309 to amino acid 667 and was chosen to avoid pick-up of proteins that are known to interact with the N-terminus of MID1 (Trockenbacher et al. 2001). Interestingly, this method identified two full-length EF-1 $\alpha$ (NM_001402) clones that could be confirmed to show specific interaction with MID1. The interaction site on MID1 was mapped to the SPRY/PRY domain at the C-terminus of MID1, namely to amino acids 474-667, by yeast two-hybrid assays (Fig. 1a). Further corroboration for the interaction of MID1 with EF- $1 \alpha$ was achieved by showing co-localisation of EF- $1 \alpha$ with the microtubuleassociated protein MID1 by immunofluorescence (Fig. 1c). While overexpression of EF- $1 \alpha$ alone in COS-7 cells resulted in a mostly diffuse staining in the cytosol, co-expression with full-length MID1 in the same cells resulted in a marked shift of EF- $1 \alpha$ to the cytoskeleton, clearly indicating a scavenging of EF- $1 \alpha$ to the microtubules by its binding to MID1. 
Fig. 1 a EF- $1 \alpha$ interacts with the MID1 protein. a Deletion mapping of the EF- $1 \alpha$ binding site on the MID1 protein in a yeast two-hybrid assay. While two C-terminal peptides (aa 311 aa 667 and aa 474- aa 667) show clear binding to EF- $1 \alpha$ fulllength protein, no binding was seen with any of the shorter constructs, as indicated on the right panel by the appearance or lack of yeast growth, respectively. b Yeast two-hybrid interaction assay between EF- $1 \alpha$ full-length and two mutated MID1 variants as found in Opitz syndrome patients. Both MID1 mutations result in a frame shift and a truncation of the resulting MID1 proteins. The upper MID1 variant harbours a $4 \mathrm{bp}$ deletion at position 1800 and the lower one a G-insertion at position 1558 resulting in a wrong reading frame after amino acid 600 and 519, respectively (arrows), the hatched regions indicate the amino acid sequence corresponding to the wrong reading frame until the first stop codon is reached. On the right panel the respective parts of the yeast plates are shown; they show no growth and hence no interaction. c Immunofluorescence microscopy of COS-7 cells transiently transfected with ECFP-MID1 and $\mathrm{EF}-1 \alpha$ (upper panel) and EF- $1 \alpha$ alone (lower panel). The distribution of EF- $1 \alpha$ when expressed alone shows a diffuse cytoplasmic staining patter, whereas co-expressed with ECFP-MID1 it co-localises with ECFP-MID1 at the microtubules

By contrast, two different mutant MID1 constructs failed to show interaction with EF- $1 \alpha$ in a yeast two-hybrid experiment (Fig. 1b). Both clones contained the entire MID1 open reading frame, but carried point mutations, which have been previously identified in OS patients, and led to a Cterminal truncation of the protein [insertion of a $\mathrm{G}$ at nucleotide position 1558 (Quaderi et al. 1997) and a deletion of four nucleotides at position 1800 (Schweiger et al. 1999)]. This confirms that the EF- $1 \alpha$ binding domain in MID1 is at its C-terminus and suggests an important role for this protein interaction in the pathogenesis of OS. Moreover, it gives further evidence of the specificity of the yeast twohybrid experiments, since it was shown that a single point mutation in MID1 inhibits yeast growth.
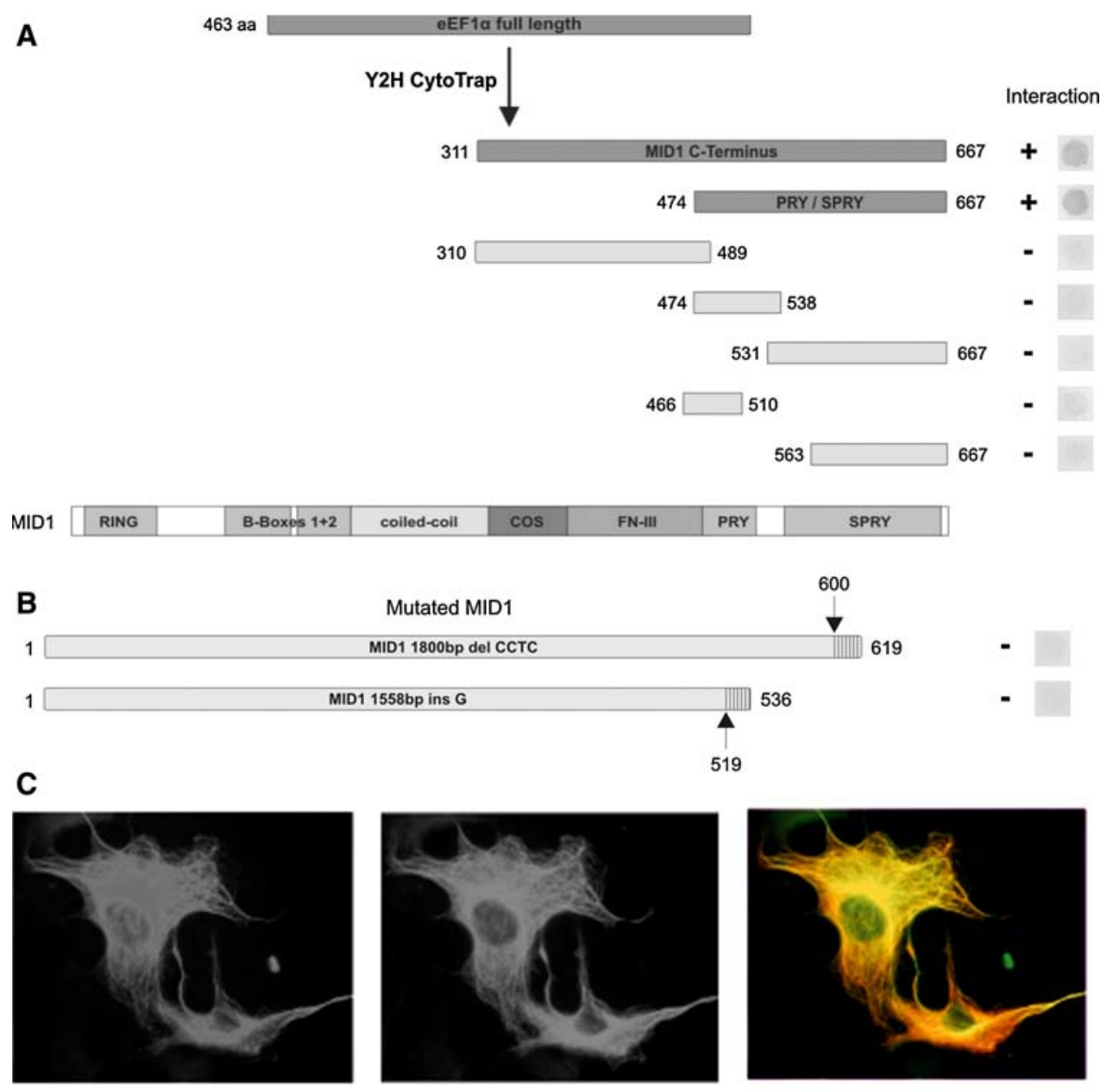

$\mathrm{EF}-1 \alpha$

Merge

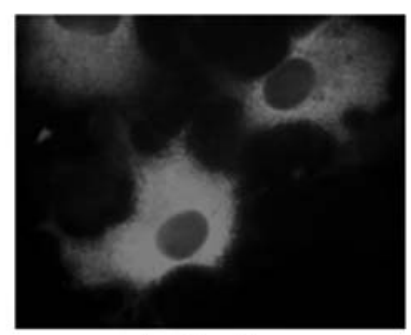

EF- $1 \alpha$ alone

Identification of components of the MID1/ $\alpha 4$ protein complex

Interaction of the MID1 protein with $\alpha 4$ has previously been demonstrated (Trockenbacher et al. 2001). Using deletion analysis guided by domain prediction (Schneider 1992), we narrowed the MID1 protein-binding region of $\alpha 4$ to a 44 amino acid (aa) peptide between aa 236 and 280. To identify proteins able to interact with the MID1/ $\alpha 4$ complex, this peptide was immobilised to a column, and affinity chromatography was performed using HeLa cell lysates. To avoid competition between endogenous $\alpha 4$ and the immobilised peptide, $\alpha 4$ was down-regulated by RNA interference (RNAi) in the cells prior to lysate 
A
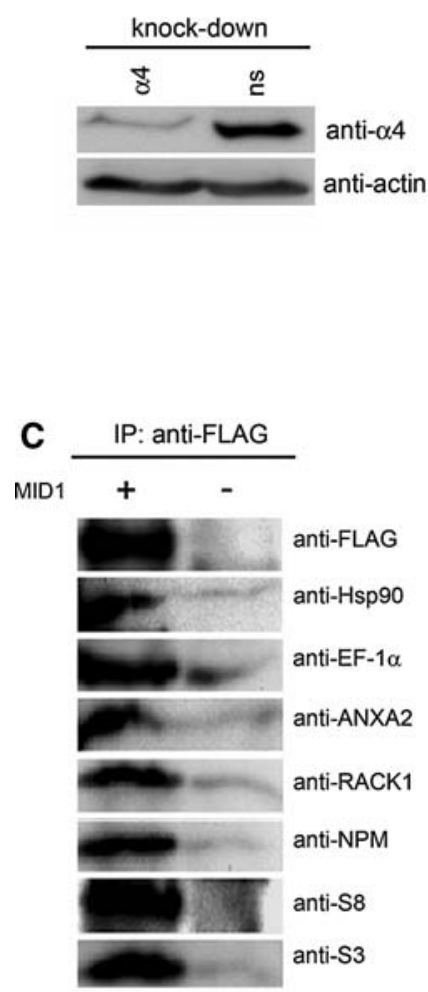

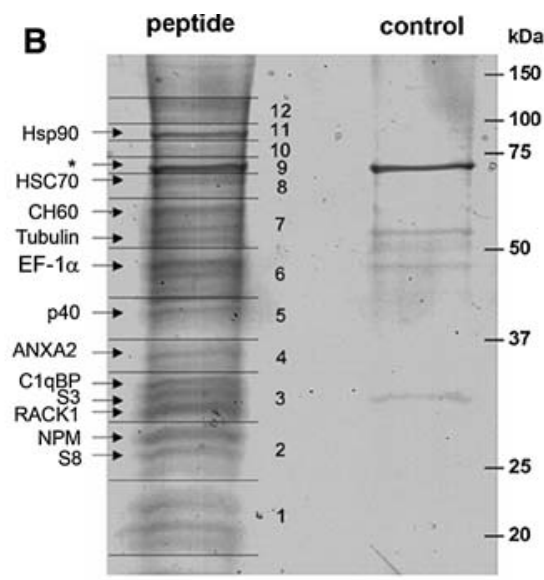

D

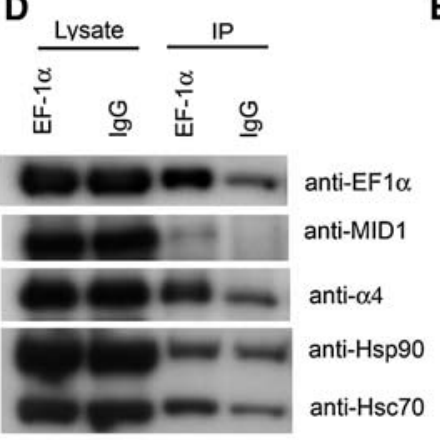

E

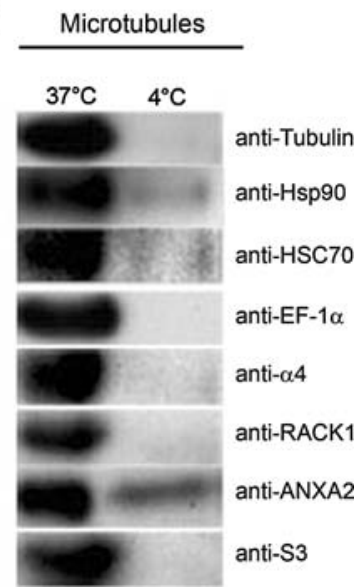

Fig. 2 a Knockdown of $\alpha 4$ protein in HeLa cells- $\alpha 4$ protein in HeLa cell lysates after transfection with a specific $\alpha 4$ RNAi oligonucleotide ( $\alpha 4$, first lane) or a non-silencing oligonucleotide (ns, second lane) are shown. Detection of actin was used as loading control. b SDS-gel stained with colloidal Coomassie showing the proteins eluted from streptavidin beads coupled to a biotinylated 44 aa $\alpha 4$ peptide (left lane) or from unmodified beads (right lane). Differential bands were excised and analysed by mass spectrometry. Protein identities are given. The asterisk indicates the position of the MID1 protein band, which is masked by an abundant $E$. coli band derived protein band contaminating the eluting peptide (also present in the control). $\mathbf{c}$ Co-immunoprecipitation of FLAG-MID1 with different components of the complex. HeLa cell lysates overexpressing FLAG-MID1 were immunoprecipi-

production (Fig. 2a). After extensive washing, specifically bound proteins were eluted from the column with an excess of free 44 aa peptide, separated on an SDS gel and stained with colloidal Coomassie. As control experiment, lysates of HeLa cells after $\alpha 4$ knockdown were passed through a column without peptide. Proteins specifically eluting from the peptide column were extracted from the gel and analysed by electrospray ionisation (ESI) mass spectrometry (Fig. 2b). Interestingly, in addition to the tubulin beta-5 chain, a known interaction partner of MID1 (Schweiger et al. 1999), EF-1 $\alpha$ was purified on the affinity chromatography column and identified in the mass spectrophotometer, confirming the yeast tated with anti-FLAG antibody (left lane). Western blots were incubated with specific antibodies against the respective proteins. HeLa cell lysates without FLAG-MID1 overexpression were used as background control (right lane). d Co-immunoprecipitation of endogenous EF-1 $\alpha$ with MID1, $\alpha 4$, Hsp90 and Hsc70. HeLa cell lysates were immunoprecipitated with anti-EF1 $\alpha$ (lanes 1 and 3 ) or with unspecific IgGs (lanes 2 and 4 ). Input lysates (lanes 1 and 2) and immunoprecipitates (lanes 3 and 4) were loaded on an SDS-Page and analysed with anti-EF- $1 \alpha$, anti-MID1, anti- $\alpha$ (, anti-Hsp90 and anti-Hsc70 antibodies. e Microtubule-association of the complex partners. Pellets from microtubule-assembly experiments at $37^{\circ} \mathrm{C}$ (left lane) and $4{ }^{\circ} \mathrm{C}$ (right lane) were dissolved and loaded on a Western blot and detected with the respective antibodies

two-hybrid and immunofluorescence results. Besides that, several 40S ribosomal proteins [S8, S3, 40S ribosomal protein SA (p40)], and ribosome- and translationassociated proteins [receptor of activated protein kinase C1 (RACK1), Nucleophosmin (NPM), heat shock cognate $71 \mathrm{kDa}$ protein (Hsc70), heat shock protein HSP90-beta $(\mathrm{Hsp} 90 \beta)$, heat shock protein $60 \mathrm{kDa}, \mathrm{Q}$ subcomponent binding protein $(\mathrm{C} 1 \mathrm{qBP})]$ were identified in approximately equimolar ratios (Fig. 2b, Table 1), suggesting a translation related function for this complex. This hypothesis is consistent with the additional presence of mRNA-binding proteins such as NPM and Annexin A2 (ANXA2) in the complex. 


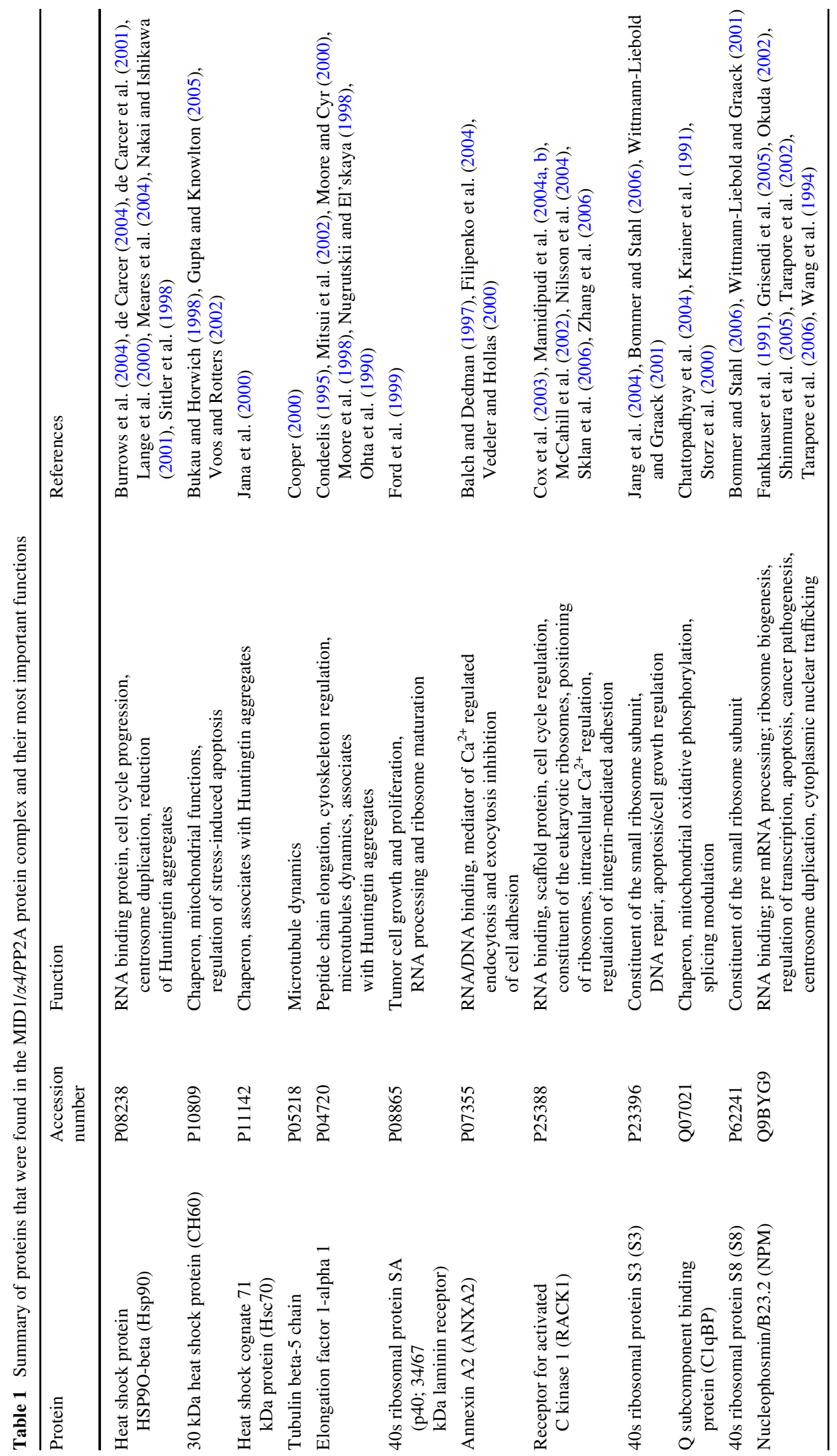


To confirm specific interactions of the identified proteins with MID1, we overexpressed FLAG-tagged MID1 (FLAGMID1) in HeLa cells and performed co-immunoprecipitation (IP) experiments using agarose beads coated with antiFLAG antibody. Immunoprecipitates were analysed on a Western blot using antibodies detecting the respective endogenous proteins. Immunoprecipitated cell lysates of HeLa cells containing the empty vector were used as a control for background. Specific co-precipitation of each of the identified proteins with FLAG-MID1 was observed (Fig. 2c). As a control for the specificity of the immunoprecipitation, we used an antibody detecting hnRNPA1, which was not present in any of the pull downs (data not shown).

For further in vivo evidence, EF- $1 \alpha$ was immunoprecipitated using either a specific anti-EF- $1 \alpha$ antibody or unspecific mouse immunoglobulins (IgGs) as negative control. Immunoprecipitates were analysed with specific antiMID1, anti- $\alpha 4$, anti-Hsp90 and anti-Hsc70 antibodies detecting the endogenous proteins. All proteins analysed were enriched when the complex was immunoprecipitated with the anti-EF-1 $\alpha$ antibody (Fig. $2 \mathrm{~d}$ ), therefore proving co-precipitation of these proteins.

Furthermore, in confirming our previous findings regarding MID1 (Schweiger et al. 1999), all investigated components of the complex, including EF- $1 \alpha$, were enriched in pelleted purified microtubules, corroborating association of the complex with microtubules (Fig. 2e). After ultracentrifugation of HeLa cell lysates in order to remove insoluble proteins, we performed purification of microtubules at both 37 and $4{ }^{\circ} \mathrm{C}$. While examination at $37^{\circ} \mathrm{C}$ allows efficient repolymerisation of depolymerised microtubules as a basis for the enrichment of purified microtubules, cold-shock conditions at $4{ }^{\circ} \mathrm{C}$ inhibit microtubule-polymerisation (Rubin and Weiss 1975). Bands detected with all relevant antibodies were exclusively present or much stronger in the fraction containing purified microtubules as compared to the cold-shocked fraction (Fig. 2E, right lane).

\section{The MID1/ $\alpha 4$ complex associates with RNA}

EF- $1 \alpha$ association with MID1 and integration of RNAbinding proteins such as NPM, RACK1 and ANXA2 in the complex suggested that RNA might also be present. To find out whether the MID1 complex associates with RNA in vivo, FLAG-MID1 from cytosolic fractions of FLAGMID1 overexpressing and, as control, non-overexpressing HeLa cells were immunoprecipitated using an anti-FLAG antibody. After protein and DNA digestion, RNA was extracted from the eluted fractions, labelled with $\left[5^{\prime}-\right.$ $\left.{ }^{32} \mathrm{P}\right] \mathrm{pCp}$, and analysed in a scintillation counter and by agarose gel electrophoresis. As expected, this experiment revealed a marked enrichment of RNA in the specific immunoprecipitate in comparison to the control (Fig. 3).
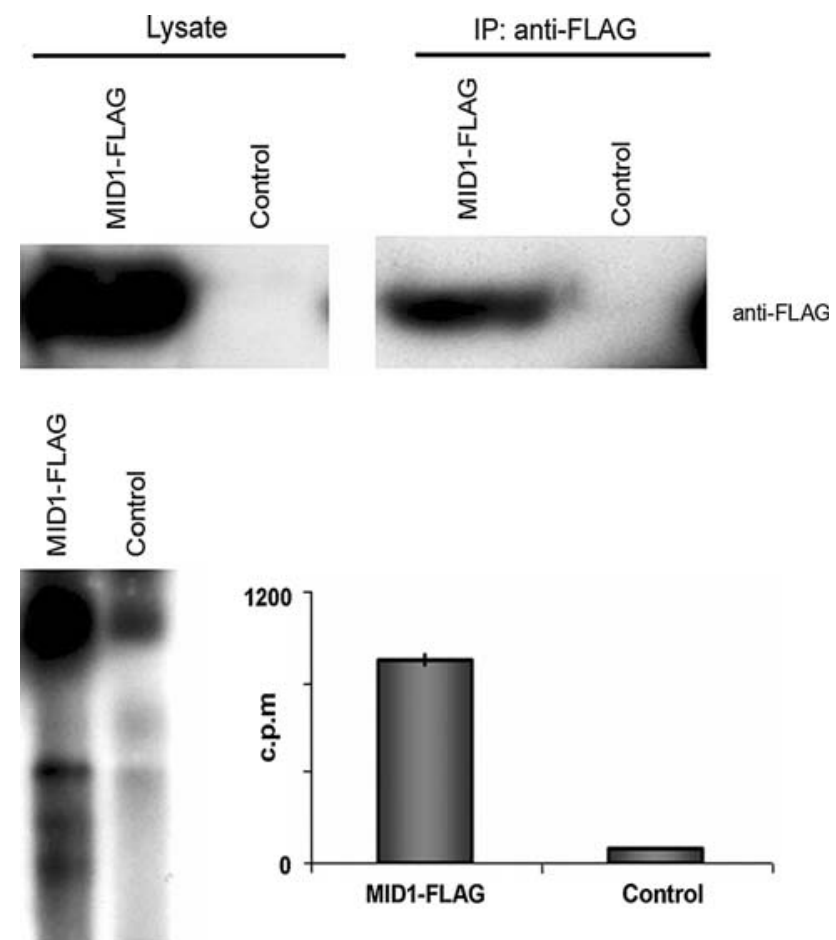

Fig. 3 The MID1 protein complex associates with RNA. Cytosol of HeLa cells with (FLAG-MID1) and without (control) FLAG-MID1 overexpression were immunoprecipitated using an anti-FLAG antibody. Immunoblots of lysates (upper left panel) and immunoprecipitates (upper right panel) probed with an anti-FLAG antibody are shown. RNA was isolated from the samples, labelled with $\left[5^{\prime}-{ }^{32} \mathrm{P}\right] \mathrm{pCp}$ and analysed on an agarose gel (lower left panel) and in a scintillation counter (lower right panel)

The MID1/ $\alpha 4$ complex associates preferentially with poly-rG homoribopolymers

To analyse if the RNA-binding activity of the identified complex shows some sequence specificity, cytosolic fractions from FLAG-MID1 overexpressing HeLa cells were incubated with agarose immobilised RNA homoribopolymers (poly-rA, -rU, -rC and -rG). Similar assays have been previously used for the characterisation of RNA-binding properties of many RNA-binding proteins (Filipenko et al. 2004; Siomi et al. 1993). After extensive washing, the bound proteins were eluted and analysed by Western blot. Using the respective antibody panel, specific bands corresponding to FLAG-MID1, Hsp90, Hsc70, EF-1 $\alpha, \alpha 4$ and RACK1 could be detected in the poly-rG sample, again confirming co-fractionation of these proteins. Fainter bands were seen in the poly-rU sample, while almost no bands appeared in the poly-rA or poly-rC sample, proving the specificity of the reaction (Fig. 4a). To discard the possibility that the enrichment in the poly-rG and poly-rU 


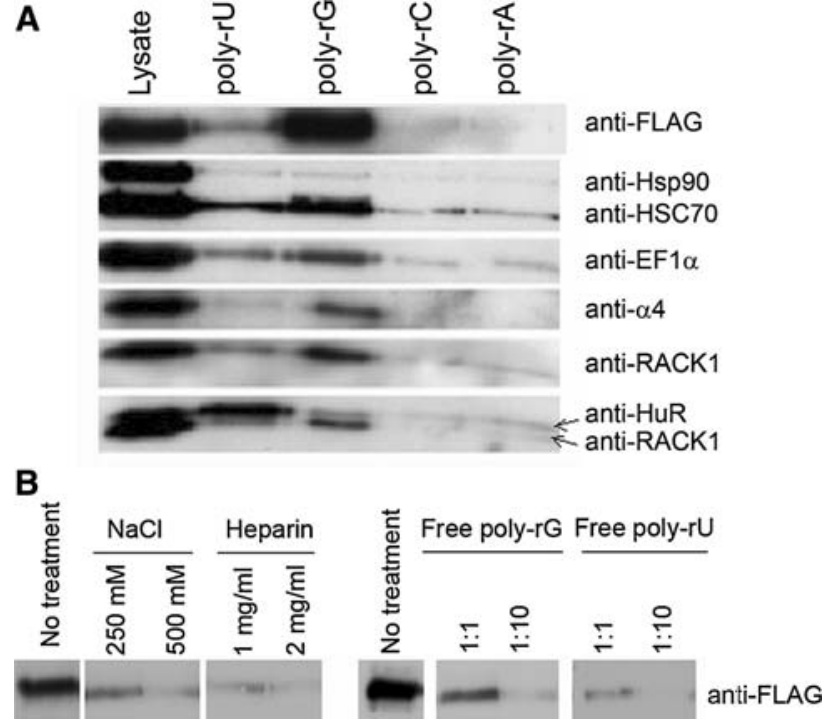

Fig. 4 Association of FLAG-MID1 and some of the complex partners with poly-ribonucleotides. a Lysates from FLAG-MID1 overexpressing HeLa cells were incubated with immobilised poly-rU (lane 2), poly-rG (lane 3), poly-rC (lane 4) or poly-rA (lane 5), washed and boiled at $95^{\circ} \mathrm{C}$. Lysate (lane 1) and eluted fractions were immunoblotted and analysed with the respective antibodies. Poly-rU binding HuR protein was used as control. b Influence of free poly-rG and poly-rU competitors and increasing salt or heparin concentrations on the FLAG-MID1/poly-rG interaction

fractions were unspecific or an artefact, we tested the same blot with an antibody detecting the well-known poly-rU binding HuR protein (Lopez de Silanes et al. 2004). As expected, HuR was found to predominantly associate with poly-rU and faintly with poly-rG homoribopolymers. Increasing concentrations of free poly-rG (bound:free, 1:1 and 1:10) as well as of salt (250 and $500 \mathrm{mM} \mathrm{NaCl})$ and heparin $(1$ and $2 \mathrm{mg} / \mathrm{ml})$ significantly reduced the binding of FLAG-MID1 protein to poly-rG coated beads (Fig. 4b), additionally proving specificity of the binding.

The MID1 protein complex assembles its own mRNA

Association of mRNPs with mRNAs coding for proteins that are components of the respective complexes is a widely observed phenomenon. Knowing that mRNA localisation to the cytoskeleton is often driven by sequences found in the 3'UTR (Lopez de Heredia and Jansen 2004), we screened the 3'UTR of the MID1 gene for G-rich and U/Trich regions and interspecies conservation of those. Interestingly, we could detect six different regions that were both G- and/or U/T rich, and also highly conserved between human, dog and rat (Fig. 5a), which make them putative candidates responsible for the binding to the MID1/PP2A mRNP complex.

Consequently, in order to check if MID1 mRNA is incorporated into the MID1 mRNP complex, we overexpressed

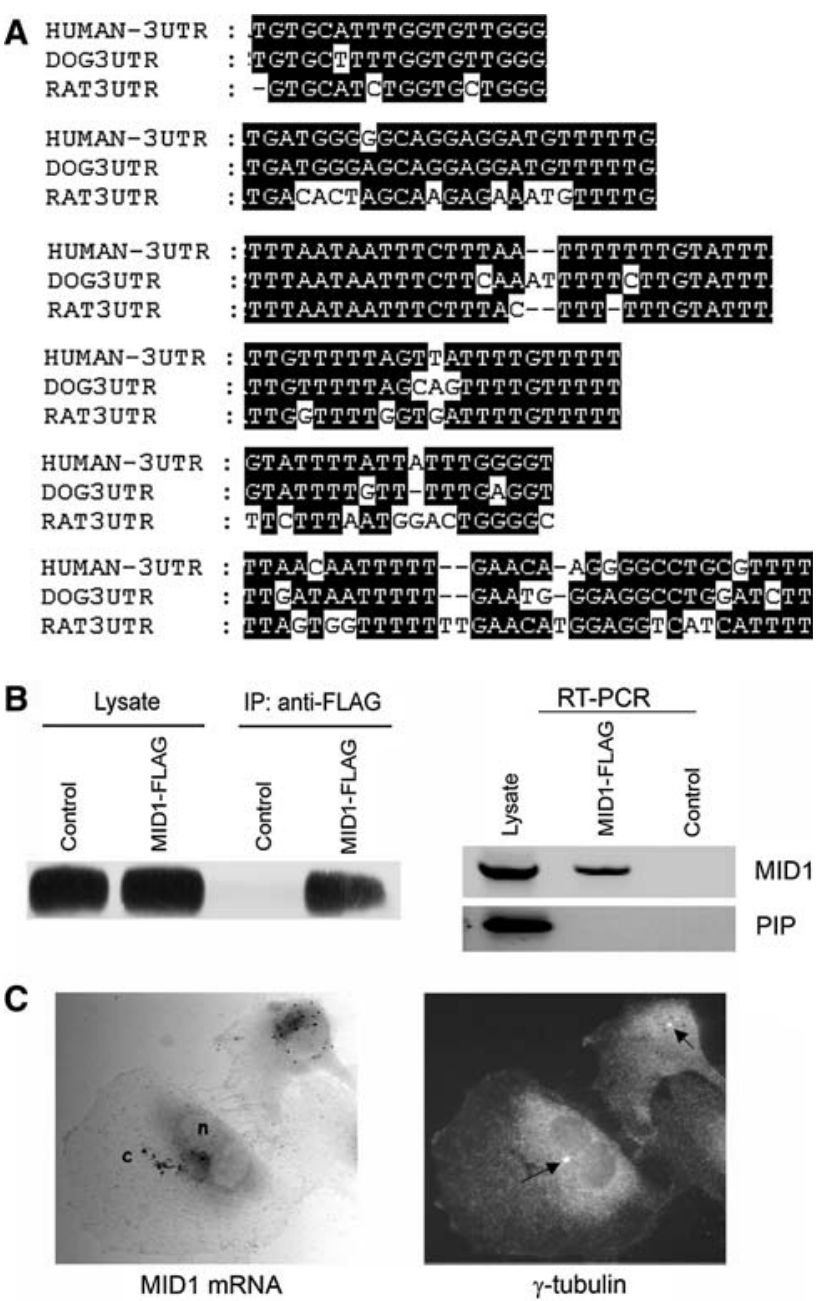

Fig. 5 The MID1 complex assembles its own mRNA. a G and U-rich sequences present in the MID1 3'UTR that show a high interspecies conservation. Positions $3^{\prime}$ to the translational stop codon are (from top to bottom) 3101, 3172, 185, 1502, 2441 and $2644 \mathrm{bp}$. Accession number NM_000381. b HeLa cells were transfected with FLAG-MID1 and subjected to RNP coimmunoprecipitation. Subsequently, RNA was isolated from the precipitation and subjected for RT-PCR using MID1 and PIP-specific primers. Immunoprecipitation was done with mouse IgG as a negative control. $\mathbf{c}$ The MID1 mRNA localises to the centrosomal region. The endogenous MID1 mRNA was detected in U373 cells by in situ hybridisation using a pool of six different digoxigeninlabelled oligonucleotides specific for the MID1 sequence and alkaline phosphatase-linked anti-digoxigenin antibody with NBT/BCIP as substrate. The centrosome was co-stained by a mouse anti- $\gamma$-tubulin antibody and an FITC-linked anti-mouse antibody (see arrows). $n$ nucleus, $c$ cytoplasm

FLAG-MID1 in HeLa cells and immunoprecipitated the protein with an anti-FLAG antibody. RNA was extracted from the immunoprecipitate, and cDNA was synthesised and used for RT-PCR using MID1 specific primers. A specific band covering from exon 4 to the $3^{\prime}$ UTR of the MID1 gene could be amplified in the anti-FLAG containing sample, while no band was detected in the negative control, reactions of which were performed with unspecific 
immunoglobulins instead of with a specific anti-FLAG antibody. Also, no specific band was detected after amplification with primers specific for PIP, which was randomly chosen and did not associate with the MID1 mRNP complex (Fig. 5b).

Binding of endogenous MID1 mRNA to the MID1 protein complex would imply that it is located at the microtubules. To determine MID1 mRNA localisation, we performed an RNA in-situ hybridisation using digoxigeninlabelled oligonucleotides complementary to specific MID1 sequences. Interestingly, we could show clear co-localisation of the MID1 mRNA with the centrosome as confirmed by a $\gamma$-tubulin stain. As a control, we used an antisense probe, which showed no defined localisation, confirming the specific association of the MID1 mRNA with the microtubule-organising centre (Fig. 5c).

\section{Discussion}

The MID1/ $\alpha 4$ complex associates with several factors involved in translation regulation

We have identified several new members of the MID1/ $\alpha 4$ complex, dysfunction of which underlies the pathogenesis of OS. In addition to its previously characterised association with tubulin (Schweiger et al. 1999), we have shown here that the MID1/ $\alpha 4$ complex also interacts with EF- $1 \alpha$ as well as with the 40S ribosomal proteins S3 and S8. Moreover, NPM, RACK1 and p40 (precursor molecule of the laminin receptor), all of which have previously been found to associate with the $40 \mathrm{~S}$ ribosomal subunit and/or to have a central role in translational control (Ford et al. 1999; Nilsson et al. 2004; Okuwaki et al. 2002), co-purified with this protein complex. Of note, EF1- $\alpha$, a well-known and essential player in protein translation and an important polysomal component with RNA-binding properties, was independently identified in a yeast two-hybrid screen with MID1 as bait and showed perfect co-localisation with MID1 at the microtubules. Interaction of MID1 and EF- $1 \alpha$ in the yeast two-hybrid system was abolished by a single point mutation. Furthermore, co-precipitation of both proteins was demonstrated (1) after overexpression and immunoprecipitation of FLAG-MID1, (2) after immunoprecipitation of endogenous EF- $1 \alpha$ and (3) in a microtubule-assembly assay. While EF- $1 \alpha$ is one of the most abundant proteins in the cell and is known to artificially show up in large-scale screens searching for protein-protein interaction, our data as a total gave very strong evidence for a specific and biologically relevant interaction between MID1 and EF- $1 \alpha$.

In this study, we could narrow the domain that is responsible for the interaction between MID1 and EF- $1 \alpha$ to the
SRPY/PRY domain in the C-terminus of the MID1 protein. Regarding the numerous cellular functions that proteins with SRPY/PRY domains perform (Meroni and Diez-Roux 2005; Rhodes et al. 2005), it would be interesting to see if EF- $1 \alpha$ also interacts with others of these proteins.

We also showed that the MID1/ $\alpha 4$ complex associates with RNA, particularly with poly-rG and poly-rU sequences, suggesting a specific association of the complex with a subset of RNAs. Further IP experiments, sequential microtubule preparations and immunofluorescence collectively establish that the MID1/ $\alpha 4 / \mathrm{PP} 2 \mathrm{~A}$ complex forms part of the core of a microtubule-associated multiprotein complex including several translation factors and RNA, suggesting that it might influence the protein synthesis of associated mRNAs. Interestingly, neither the MID1 protein itself nor the $\alpha 4$ protein or PP2A contain one of the known RNA-binding domains (according to the program RNABindR: http://bindr.gdcb.iastate.edu/RNABindR), which suggests that other interaction partners with RNA-binding properties, like EF-1 $\alpha$ (Lamberti et al. 2004), NPM (Yang et al. 2002), RACK1 (Angenstein et al. 2002) and/or ANXA2 (Filipenko et al. 2004) are the RNA-binding components in the complex and interactions between FLAGMID1 and $\mathrm{rG}$ and $\mathrm{rU}$ homoribopolymers or the MID1 mRNA are indirect associations.

The fact that MID1 and its protein complex partners interact with the MID1 mRNA points at a putative feedback regulatory role MID1 has on its own synthesis. In an RNA in-situ hybridisation experiment, we saw that the endogenous MID1 mRNA localises to the microtubule-assembly centre. This suggests association of higher concentrations of the lowly expressed MID1 mRNA (and also possibly of the MID1 mRNP) to polymerising tubulin and to the minus end of microtubules rather than to the rest of the microtubules or a random distribution along the microtubules at equal concentrations. Similar to what is known of other mRNAs encoding embryonic patterning proteins that associate with centrosomes, it could further mean that the centromere is used to ensure asymmetric sorting of the MID1 mRNA subsequent to cell division (Lopez de Heredia and Jansen 2004).

mRNA localisation is mainly mediated by specific sequences in 3'UTRs (Lopez de Heredia and Jansen 2004). The MID1 mRNP complex has been seen to bind rG- and rU-rich sequences. Several rG- and rU-rich sequences within the MID1 3'UTR could be responsible for the binding of the mRNA to the MID1/ $\alpha 4 / \mathrm{PP} 2 \mathrm{~A}$ mRNP complex (Fig. 5a). RNA-protein pull-down assays with in vitro transcribed sequence motifs and/or an mRNA visualisation assay based on GFP-MS2 fusion protein and mRNA fused to MS2-binding sites, as developed by Singer et al. (Bertrand et al. 1998), could be used to identify the responsible sequence motif in the future. 
Translational control unit at the microtubules

The protein composition of the MID1/ $\alpha 4$ complex identified by mass spectrometry points to a newly found microtubule-associated process that links the control of the translation of specific, microtubule-associated mRNAs with elements of the mTOR / PP2A signalling cascade. Several of the identified components of the MID1 mRNP complex have been brought into context with microtubules and microtubule-associated translation regulation previously. Thus, the cytoskeleton-associated pool of EF- $1 \alpha$ is involved in bundling, stabilising and promoting the assembly of microtubules (Kumagai et al. 1999; Moore and Cyr 2000; Moore et al. 1998; Ohta et al. 1990; Shiina et al. 1994). Interactions with polo domain-containing kinases at the mitotic spindle and centrosomes have been demonstrated for Hsp90 (de Carcer et al. 2001) and NPM (Zhang et al. 2004), and close cooperation between NPM and CDK2/ cyclin $\mathrm{E}$ in centrosome duplication has been observed (Okuda 2002; Okuda et al. 2000). In addition, in fractionated protein preparations, most RACK1 molecules copurify with the cytoskeleton (Hermanto et al. 2002), and ANXA2 is one of the most abundant proteins in cytoskeleton-bound polyribosome fractions (Vedeler and Hollas 2000).

The MID1 translation control unit and development of the ventral midline

Dysfunction of the MID1/ $\alpha 4$ complex results in numerous fusion defects of the ventral midline, which is normally established through migrating and polarising cells that rely heavily on protein gradients (Schweiger and Schneider 2003). Therefore, we hypothesise that MID1-containing mRNP complexes are involved in the regulation of localised synthesis of proteins needed in asymmetric concentrations at the poles of these cells. Interestingly, MID1 mutant proteins, such as those that have been identified in patients with OS, lose the ability to interact with EF- $1 \alpha$, strongly supporting a role for the complex in protein translation. Consequently, defective regulation of translation of the associated mRNAs could result in a phenotype reminiscent of OS.

Interestingly, several of the proteins identified as interaction partners of the microtubule-associated MID1/ $\alpha 4$ complex have been involved in cell polarisation and cell migration. For example, RACK1 has been found both in cell-spreading centres in attached cells (de Hoog et al. 2004) and acting as a central switch in growth factorinduced cell migration (Cox et al. 2003; Kiely et al. 2005). Furthermore, like $\mathrm{C} 1 \mathrm{qBP}$, which is another member of the MID1 protein complex, RACK1 interacts with activated protein kinase $\mathrm{C}$ (PKC) isozymes, which are also central players in the regulation of cell spreading and focal adhesion assembly (Disatnik et al. 2002; Nance 2005; Storz et al. 2000). ANXA2 was found to rapidly localise to developing cell-cell contacts and to be essential for the formation of filopodia at the leading edges of both migrating fibroblasts and epithelial cells (Hansen et al. 2002; Nobes and Hall 1995). Finally, p40SA is the precursor of the $M_{r}$ 67,000 laminin receptor that has been classified as the prototypic cellular adhesion molecule for connecting cells and basement membranes (Liotta 1986).

Our results also imply a close interaction of a microtubule-associated translation control unit with PP2A and its negative regulators $\alpha 4$ and MID1, all essential players of mTOR signalling. The mTOR/PP2A pathway is known to regulate the translation of 5'TOP-marked mRNAs via phosphorylation of several important translation cofactors such as 4E-BP1 and S6K1 (Duvel and Broach 2004; Fingar and Blenis 2004; Peterson et al. 1999), and is also involved in developmental processes.

In summary, in addition to its role in the ubiquitin-specific regulation of microtubule-associated PP2Ac, we now find that the MID1/ $\alpha 4$ complex is the core of a microtubuleassociated mRNP complex that links cytoskeleton-associated mRNA transport and translation control factors with members of the mTOR/PP2A signalling cascade: a perfect scenario for the orchestration of complex gradient-controlled processes. Identification of RNAs binding to the MID1/ 4 4/PP2A mRNP will shed further light into these processes that take place during the development of the ventral midline.

Acknowledgments We thank Joyce So for editing this manuscript, and Susanne Freier and Hannelore Madle for tissue culturing. This work was sponsored by grants from the Volkswagen Stiftung (Lichtenberg professorship to SS), the Deutsche Forschungsgemeinschaft (SFB 577, project A6 to SS) and the Austrian Science Fund (FWF:SFB021/ 3 to RS).

\section{Reference}

Angenstein F, Evans AM, Settlage RE, Moran ST, Ling S-C, Klintsova AY, Shabanowitz J, Hunt DF, Greenough WT (2002) A Receptor for Activated C Kinase Is Part of Messenger Ribonucleoprotein Complexes Associated with PolyA-mRNAs in Neurons. J Neurosci 22:8827-8837

Balch C, Dedman JR (1997) Annexins II and V inhibit cell migration. Exp Cell Res 237:259-263

Bashirullah A, Cooperstock RL, Lipshitz HD (1998) RNA localization in development. Annu Rev Biochem 67:335-394

Bassell GJ, Singer RH (2001) Neuronal RNA localization and the cytoskeleton. Results Probl Cell Differ 34:41-56

Bertrand E, Chartrand P, Schaefer M, Shenoy SM, Singer RH, Long RM (1998) Localization of ASH1 mRNA particles in living yeast. Mol Cell 2:437-445

Bommer UA, Stahl J (2006) Ribosomal Proteins in Eukaryotes Encyclopedia of Life Sciences 
Bukau B, Horwich AL (1998) The Hsp70 and Hsp60 chaperone machines. Cell 92:351-366

Burrows F, Zhang H, Kamal A (2004) Hsp90 activation and cell cycle regulation. Cell Cycle 3:1530-1536

Condeelis J (1995) Elongation factor 1 alpha, translation and the cytoskeleton. Trends Biochem Sci 20:169-170

Condeelis J, Singer RH (2005) How and why does beta-actin mRNA target? Biol Cell 97:97-110

Cooper GM (2000) The cell: a molecular approach. 2nd edn. Boston University, Sinauer Associates

Cox EA, Bennin D, Doan AT, O'Toole T, Huttenlocher A (2003) RACK1 regulates integrin-mediated adhesion, protrusion, and chemotactic cell migration via its Src-binding site. Mol Biol Cell 14:658-669

Chattopadhyay C, Hawke D, Kobayashi R, Maity SN (2004) Human p32, interacts with B subunit of the CCAAT-binding factor, $\mathrm{CBF} /$ NF-Y, and inhibits CBF-mediated transcription activation in vitro. Nucleic Acids Res 32:3632-3641

de Carcer G (2004) Heat shock protein 90 regulates the metaphaseanaphase transition in a polo-like kinase-dependent manner. Cancer Res 64:5106-5112

de Carcer G, do Carmo Avides M, Lallena MJ, Glover DM, Gonzalez C (2001) Requirement of Hsp90 for centrosomal function reflects its regulation of Polo kinase stability. Embo J 20:2878-2884

de Hoog CL, Foster LJ, Mann M (2004) RNA and RNA binding proteins participate in early stages of cell spreading through spreading initiation centers. Cell 117:649-662

Disatnik MH, Boutet SC, Lee CH, Mochly-Rosen D, Rando TA (2002) Sequential activation of individual PKC isozymes in integrinmediated muscle cell spreading: a role for MARCKS in an integrin signaling pathway. J Cell Sci 115:2151-2163

Dreyfuss G, Kim VN, Kataoka N (2002) Messenger-RNA-binding proteins and the messages they carry. Nat Rev Mol Cell Biol 3:195-205

Duvel K, Broach JR (2004) The role of phosphatases in TOR signaling in yeast. Curr Top Microbiol Immunol 279:19-38

Fankhauser C, Izaurralde E, Adachi Y, Wingfield P, Laemmli UK (1991) Specific complex of human immunodeficiency virus type $1 \mathrm{rev}$ and nucleolar B23 proteins: dissociation by the Rev response element. Mol Cell Biol 11:2567-2575

Filipenko NR, MacLeod TJ, Yoon CS, Waisman DM (2004) Annexin A2 is a novel RNA-binding protein. J Biol Chem 279:8723-8731

Fingar DC, Blenis J (2004) Target of rapamycin (TOR): an integrator of nutrient and growth factor signals and coordinator of cell growth and cell cycle progression. Oncogene 23:3151-3171

Ford CL, Randal-Whitis L, Ellis SR (1999) Yeast proteins related to the p40/laminin receptor precursor are required for 20S ribosomal RNA processing and the maturation of $40 \mathrm{~S}$ ribosomal subunits. Cancer Res 59:704-710

Grisendi S, Bernardi R, Rossi M, Cheng K, Khandker L, Manova K, Pandolfi PP (2005) Role of nucleophosmin in embryonic development and tumorigenesis. Nature 437:147-153

Gupta S, Knowlton AA (2005) HSP60, Bax, apoptosis and the heart. J Cell Mol Med 9:51-58

Hansen MD, Ehrlich JS, Nelson WJ (2002) Molecular mechanism for orienting membrane and actin dynamics to nascent cell-cell contacts in epithelial cells. J Biol Chem 277:45371-45376

Hermanto U, Zong CS, Li W, Wang LH (2002) RACK1, an insulinlike growth factor I (IGF-I) receptor-interacting protein, modulates IGF-I-dependent integrin signaling and promotes cell spreading and contact with extracellular matrix. Mol Cell Biol 22:2345-2365

Jacinto E, Hall MN (2003) Tor signalling in bugs, brain and brawn. Nat Rev Mol Cell Biol 4:117-126

Jana NR, Tanaka M, Wang G, Nukina N (2000) Polyglutamine lengthdependent interaction of Hsp40 and Hsp70 family chaperones with truncated $\mathrm{N}$-terminal huntingtin: their role in suppression of aggregation and cellular toxicity. Hum Mol Genet 9:2009-2018

Jang CY, Lee JY, Kim J (2004) RpS3, a DNA repair endonuclease and ribosomal protein, is involved in apoptosis. FEBS Lett 560:81-85

Kiely PA, Leahy M, O'Gorman D, O'Connor R (2005) RACK1-mediated integration of adhesion and insulin-like growth factor I (IGF-I) signaling and cell migration are defective in cells expressing an IGF-I receptor mutated at tyrosines 1250 and 1251 . J Biol Chem 280:7624-7633

Kiledjian M, Dreyfuss G (1992) Primary structure and binding activity of the hnRNP U protein: binding RNA through RGG box. Embo J 11:2655-2664

Kimble M, Khodjakov AL, Kuriyama R (1992) Identification of ubiquitous high-molecular-mass, heat-stable microtubule-associated proteins (MAPs) that are related to the Drosophila 205-kDa MAP but are not related to the mammalian MAP-4. Proc Natl Acad Sci U S A 89:7693-7697

Krainer AR, Mayeda A, Kozak D, Binns G (1991) Functional expression of cloned human splicing factor SF2: homology to RNAbinding proteins, U1 70K, and Drosophila splicing regulators. Cell 66:383-394

Kumagai F, Hasezawa S, Nagata T (1999) Putative involvement of a $49 \mathrm{kDa}$ protein in microtubule assembly in vitro. Eur J Cell Biol 78:109-116

Lamberti A, Caraglia M, Longo O, Marra M, Abbruzzese A, Arcari P (2004) The translation elongation factor $1 \mathrm{~A}$ in tumorigenesis, signal transduction and apoptosis: review article. Amino Acids $26: 443-448$

Lange BM, Bachi A, Wilm M, Gonzalez C (2000) Hsp90 is a core centrosomal component and is required at different stages of the centrosome cycle in Drosophila and vertebrates. EMBO J 19:12521262

Lasko P (1999) RNA sorting in Drosophila oocytes and embryos. Faseb J 13:421-433

Liotta LA (1986) Tumor invasion and metastases-role of the extracellular matrix: Rhoads Memorial Award lecture. Cancer Res 46:1-7

Lopez de Heredia M, Jansen RP (2004) mRNA localization and the cytoskeleton. Curr Opin Cell Biol 16:80-85

Lopez de Silanes I, Zhan M, Lal A, Yang X, Gorospe M (2004) Identification of a target RNA motif for RNA-binding protein HuR. Proc Natl Acad Sci U S A 101:2987-2992

Lutsch G, Stahl J, Kargel HJ, Noll F, Bielka H (1990) Immunoelectron microscopic studies on the location of ribosomal proteins on the surface of the $40 \mathrm{~S}$ ribosomal subunit from rat liver. Eur J Cell Biol $51: 140-150$

Mamidipudi V, Chang BY, Harte RA, Lee KC, Cartwright CA (2004a) RACK1 inhibits the serum- and anchorage-independent growth of v-Src transformed cells. FEBS Lett 567:321-326

Mamidipudi V, Zhang J, Lee KC, Cartwright CA (2004b) RACK1 regulates G1/S progression by suppressing Src kinase activity. Mol Cell Biol 24:6788-6798

McCahill A, Warwicker J, Bolger GB, Houslay MD, Yarwood SJ (2002) The RACK1 scaffold protein: a dynamic cog in cell response mechanisms. Mol Pharmacol 62:1261-1273

Meares R (2004) The conversational model: an outline. Am J Psychother 58:51-66

Meroni G, Diez-Roux G (2005) TRIM/RBCC, a novel class of 'single protein RING finger' E3 ubiquitin ligases. Bioessays 27:11471157

Mitsui K, Nakayama H, Akagi T, Nekooki M, Ohtawa K, Takio K, Hashikawa T, Nukina N (2002) Purification of polyglutamine aggregates and identification of elongation factor-1alpha and heat shock protein 84 as aggregate-interacting proteins. J Neurosci 22:9267-9277

Mohr E, Richter D (2001) Messenger RNA on the move: implications for cell polarity. Int J Biochem Cell Biol 33:669-679 
Moore RC, Cyr RJ (2000) Association between elongation factor1alpha and microtubules in vivo is domain dependent and conditional. Cell Motil Cytoskeleton 45:279-292

Moore RC, Durso NA, Cyr RJ (1998) Elongation factor-1alpha stabilizes microtubules in a calcium/calmodulin-dependent manner. Cell Motil Cytoskeleton 41:168-180

Nakai A, Ishikawa T (2001) Cell cycle transition under stress conditions controlled by vertebrate heat shock factors. EMBO J 20:2885-2895

Nakamura A, Sato K, Hanyu-Nakamura K (2004) Drosophila cup is an eIF4E binding protein that associates with Bruno and regulates oskar mRNA translation in oogenesis. Dev Cell 6:69-78

Nance J (2005) PAR proteins and the establishment of cell polarity during C. elegans development. Bioessays 27:126-135

Neuhoff V, Arold N, Taube D, Ehrhardt W (1988) Improved staining of proteins in polyacrylamide gels including isoelectric focusing gels with clear background at nanogram sensitivity using Coomassie Brilliant Blue G-250 and R-250. Electrophoresis 9:255-262

Nilsson J, Sengupta J, Frank J, Nissen P (2004) Regulation of eukaryotic translation by the RACK1 protein: a platform for signalling molecules on the ribosome. EMBO Rep 5:1137-1141

Nobes CD, Hall A (1995) Rho, rac, and cdc42 GTPases regulate the assembly of multimolecular focal complexes associated with actin stress fibers, lamellipodia, and filopodia. Cell 81:53-62

Nugrutskii BS, El'skaya AV (1998) Eukaryotic translation elongation factor 1 alpha: structure, expression, functions, and possible role in aminoacyl-tRNA channeling. Prog Nucleic Acid Res Mol Biol 60:47-78

Ohta K, Toriyama M, Miyazaki M, Murofushi H, Hosoda S, Endo S, Sakai H (1990) The mitotic apparatus-associated 51-kDa protein from sea urchin eggs is a GTP-binding protein and is immunologically related to yeast polypeptide elongation factor 1 alpha. J Biol Chem 265:3240-3247

Okuda M (2002) The role of nucleophosmin in centrosome duplication. Oncogene 21:6170-6174

Okuda M, Horn HF, Tarapore P, Tokuyama Y, Smulian AG, Chan PK, Knudsen ES, Hofmann IA, Snyder JD, Bove KE, Fukasawa K (2000) Nucleophosmin/B23 is a target of CDK2/cyclin E in centrosome duplication. Cell 103:127-140

Okuwaki M, Tsujimoto M, Nagata K (2002) The RNA binding activity of a ribosome biogenesis factor, nucleophosmin/B23, is modulated by phosphorylation with a cell cycle-dependent kinase and by association with its subtype. Mol Biol Cell 13:2016-2030

Opitz J, Frias J, Gutenberger J, Pellet J (1969a) The G-syndrome of multiple congenital anomalies. BD:OAS V:95-101

Opitz J, Summitt R, Smith D (1969b) The BBB syndrome:Familial telecanthus with associated congenital anomalies. BD:OAS V:86-94

Perkins DN, Pappin DJ, Creasy DM, Cottrell JS (1999) Probabilitybased protein identification by searching sequence databases using mass spectrometry data. Electrophoresis 20:3551-3567

Peterson RT, Desai BN, Hardwick JS, Schreiber SL (1999) Protein phosphatase $2 \mathrm{~A}$ interacts with the $70-\mathrm{kDa}$ S6 kinase and is activated by inhibition of FKBP12-rapamycinassociated protein. Proc Natl Acad Sci U S A 96:4438-4442

Pokrywka NJ, Stephenson EC (1995) Microtubules are a general component of mRNA localization systems in Drosophila oocytes. Dev Biol 167:363-370

Quaderi NA, Schweiger S, Gaudenz K, Franco B, Rugarli EI, Berger W, Feldman GJ, Volta M, Andolfi G, Gilgenkrantz S, Marion RW, Hennekam RC, Opitz JM, Muenke M, Ropers HH, Ballabio A (1997) Opitz G/BBB syndrome, a defect of midline development, is due to mutations in a new RING finger gene on Xp22. Nat Genet 17:285-291

Rhodes DA, de Bono B, Trowsdale J (2005) Relationship between SPRY and B30.2 protein domains. Evolution of a component of immune defence? Immunology 116:411-417
Rubin RW, Weiss GD (1975) Direct biochemical measurements of microtubule assembly and disassembly in Chinese hamster ovary cells. The effect of intercellular contact, cold, D2O, and N6,O2'dibutyryl cyclic adenosine monophosphate. J Cell Biol 64:42-53

Schneider R (1992) The human protooncogene ret: a communicative cadherin? Trends Biochem Sci 17:468-469

Schweiger S, Foerster J, Lehmann T, Suckow V, Muller YA, Walter G, Davies T, Porter H, van Bokhoven H, Lunt PW, Traub P, Ropers HH (1999) The Opitz syndrome gene product, MID1, associates with microtubules. Proc Natl Acad Sci U S A 96:2794-2799

Schweiger S, Schneider R (2003) The MID1/PP2A complex: a key to the pathogenesis of Opitz BBB/G syndrome. Bioessays 25:356-366

Shiina N, Gotoh Y, Kubomura N, Iwamatsu A, Nishida E (1994) Microtubule severing by elongation factor 1 alpha. Science 266:282-285

Shinmura K, Tarapore P, Tokuyama Y, George KR, Fukasawa K (2005) Characterization of centrosomal association of nucleophosmin/B23 linked to Crm1 activity. FEBS Lett 579:6621-6634

Short KM, Hopwood B, Yi Z, Cox TC (2002) MID1 and MID2 homoand heterodimerise to tether the rapamycin-sensitive $\mathrm{PP} 2 \mathrm{~A}$ regulatory subunit, Alpha 4, to microtubules: implications for the clinical variability of X-linked Opitz GBBB syndrome and other developmental disorders. BMC Cell Biol 3:1

Siomi H, Siomi MC, Nussbaum RL, Dreyfuss G (1993) The protein product of the fragile $\mathrm{X}$ gene, FMR1, has characteristics of an RNA-binding protein. Cell 74:291-298

Sittler A, Walter S, Wedemeyer N, Hasenbank R, Scherzinger E, Eickhoff H, Bates GP, Lehrach H, Wanker EE (1998) SH3GL3 associates with the Huntingtin exon 1 protein and promotes the formation of polygln-containing protein aggregates. Mol Cell 2:427-436

Sklan EH, Podoly E, Soreq H (2006) RACK1 has the nerve to act: structure meets function in the nervous system. Prog Neurobiol 78:117-134

Storz P, Hausser A, Link G, Dedio J, Ghebrehiwet B, Pfizenmaier K, Johannes FJ (2000) Protein kinase C [micro] is regulated by the multifunctional chaperon protein p32. J Biol Chem 275:24601-24607

Tarapore P, Okuda M, Fukasawa K (2002) A mammalian in vitro centriole duplication system: evidence for involvement of CDK2/cyclin $\mathrm{E}$ and nucleophosmin/B23 in centrosome duplication. Cell Cycle 1:75-81

Tarapore P, Shinmura K, Suzuki H, Tokuyama Y, Kim SH, Mayeda A, Fukasawa K (2006) Thr199 phosphorylation targets nucleophosmin to nuclear speckles and represses pre-mRNA processing. FEBS Lett 580:399-409

Trockenbacher A, Suckow V, Foerster J, Winter J, Krauss S, Ropers HH, Schneider R, Schweiger S (2001) MID1, mutated in Opitz syndrome, encodes an ubiquitin ligase that targets phosphatase 2A for degradation. Nat Genet 29:287-294

Vallee RB (1982) A taxol-dependent procedure for the isolation of microtubules and microtubule-associated proteins (MAPs). J Cell Biol 92:435-442

Vedeler A, Hollas H (2000) Annexin II is associated with mRNAs which may constitute a distinct subpopulation. Biochem J 348(Pt 3):565-572

Voos W, Rottgers K (2002) Molecular chaperones as essential mediators of mitochondrial biogenesis. Biochim Biophys Acta 1592:51-62

Wang D, Baumann A, Szebeni A, Olson MO (1994) The nucleic acid binding activity of nucleolar protein B23.1 resides in its carboxylterminal end. J Biol Chem 269:30994-30998

Webster PJ, Liang L, Berg CA, Lasko P, Macdonald PM (1997) Translational repressor bruno plays multiple roles in development and is widely conserved. Genes Dev 11:2510-2521

Wittmann-Liebold B and Graack HR (2001) Ribosomal Proteins: Structure and Evolution. Encyclopedia of Life Sciences 
Yang C, Maiguel DA, Carrier F (2002) Identification of nucleolin and nucleophosmin as genotoxic stress-responsive RNA-binding proteins. Nucleic Acids Res 30:2251-2560

Zalfa F, Bagni C (2005) Another view of the role of FMRP in translational regulation. Cell Mol Life Sci 62:251-252

Zhang H, Shi X, Paddon H, Hampong M, Dai W, Pelech S (2004) B23/ nucleophosmin serine 4 phosphorylation mediates mitotic functions of polo-like kinase 1. J Biol Chem 279:35726-35734
Zhang W, Zong CS, Hermanto U, Lopez-Bergami P, Ronai Z, Wang LH (2006) RACK1 recruits STAT3 specifically to insulin and insulin-like growth factor 1 receptors for activation, which is important for regulating anchorage-independent growth. Mol Cell Biol 26:413-424 